\title{
GB virus $C /$ hepatitis $G$ virus infection in HIV infected patients with haemophilia despite treatment with virus inactivated clotting factor concentrates
} Joachim Woelfle, Thomas Berg, Ralf Bialek, Klaus Michael Keller, Wolfgang Effenberger,
Norbert Wagner
Department of

Paediatrics, Children's

Hospital, University of

Bonn, 53113 Bonn,

Germany

J Woelfle

R Bialek

K M Keller

N Wagner

Institute of

Experimental

Haematology and

Transfusion Medicine,

University of Bonn,

Campus Charité

W Effenberger

Virchow Hospital,

Department of

Hepatologyl

Gastroenterology,

University of Berlin,

13353 Berlin, Germany

T Berg

Correspondence to: Dr Woelfle, Zentrum $\mathrm{f}$.

Kinderheilkunde, Rhein.

Friedrich-Wilhelms-

Universität, Adenauerallee

119, D-53113 Bonn,

Germany

Accepted 23 December 1998

\begin{abstract}
Aim-To determine the frequency of GB virus $C$ (GBV-C)/hepatitis G virus (HGV) infection before and after switch to the use of virus inactivated concentrates in haemophiliac patients infected with human immunodeficiency virus (HIV).

Patients and methods-Initial and follow up sera from 49 children with haemophilia were analysed for the presence of $\mathrm{GBV}-\mathrm{C} /$ HGV RNA and antibodies to HGV (antiHGV). All patients had been infected with HIV while receiving concentrates without virus inactivation before 1984 and were subsequently treated with virus inactivated concentrates.

Results-In the first available serum sample (1987 or later), two of 49 patients were GBV-C/HGV RNA positive and two further patients were anti-HGV positive. During follow up (mean, 6 years), 14 patients developed markers of GBV-C/ HGV infection. Eleven of these had received no blood products except clotting factor concentrates that had been prepared with virus inactivation.

Conclusions-Despite being treated with virus inactivated clotting factor concentrates, HIV positive patients with haemophilia are at an increased risk of manifesting GBV-C/HGV infection. We hypothesise that GBV-C/HGV is transmitted by these clotting factor concentrates. However, we cannot rule out the emergence of markers of GBV-C/HGV infection as a result of the progression of immune impairment in the course of HIV infection.

(Arch Dis Child 1999;80:429-432)
\end{abstract}

Keywords: hepatitis G virus; GB virus C; haemophilia; HIV

Recently, two novel flavivirus-like viruses, GB virus $\mathrm{C}(\mathrm{GBV}-\mathrm{C})$ and hepatitis $\mathrm{G}$ virus (HGV) have been detected in serum samples of individuals with idiopathic hepatitis. ${ }^{1-3}$ Further characterisation revealed both to be subtypes of the same virus. Although an association of GBV-C/HGV with fulminant hepatitis has been described, ${ }^{45}$ most infected persons do not show clinical or biochemical signs of liver disease. ${ }^{6-9}$
In recipients of clotting factor concentrates prepared without virus inactivation, GBV-C/ $\mathrm{HGV}$ infection rates of $9-24 \%$ have been reported. ${ }^{31011}$ A study in Spanish patients with haemophilia who received virus inactivated clotting factor concentrates showed a prevalence of GBV-C/HGV infection of 3\%, not significantly greater than that found in blood donors $(1.5 \%) .{ }^{12}$ However, GBV-C/HGV RNA has been detected in clotting factor concentrates prepared with virus inactivation by several manufacturers. ${ }^{13}$

We undertook our study to determine the frequency of GBV-C/HGV infection in German patients with haemophilia who had been infected with HIV and in some cases with hepatitis B virus (HBV), hepatitis C virus (HCV), or delta agent (HDV) before 1984 by receiving concentrates prepared without virus inactivation. Between 1983 and 1984 the treatment was switched to virus inactivated clotting factor concentrates in all patients. Attention was focused on whether GBV-C/HGV infection occurred in the follow up of initially GBVC/HGV RNA negative patients during treatment with virus inactivated concentrates.

\section{Patients and methods}

PATIENTS

Between 1984 and 1985, we followed 155 paediatric patients with haemophilia; 62 of these were seropositive for HIV infection. From March 1987, 49 of these 62 patients were followed up in our paediatric clinic for immune disorders. In a retrospective study, we analysed the virological and clinical characteristics of these patients over 2-7 years (median, 6 years 10 months). The median age at presentation was 14 years 5 months (range, 5-18 years). Before 1983, all patients had received commercial clotting factor concentrates from different manufacturers for more than two years. Between 1983 and 1984, treatment was switched to virus inactivated clotting factor concentrates in all cases. Inactivation methods included dry heating at $80^{\circ} \mathrm{C}$, vapour heating, solvent/detergent, and pasteurisation. Two patients had been treated for their coagulation disorder by other institutions and were under our supervision only for management of their HIV infection; both had received only virus inactivated preparations from 1984 onwards, but the exact nature of the preparation(s) used could not be ascertained. Forty two patients had haemophilia A and seven had haemophilia 
Table $1 \mathrm{GBV}-\mathrm{C} / \mathrm{HGV}$ status in relation to $C D 4^{+} \mathrm{T}$ cell count in $49 \mathrm{HIV}$ infected patients with haemophilia during treatment with virus inactivated clotting factor concentrates

\begin{tabular}{|c|c|c|c|c|c|c|}
\hline & \multicolumn{3}{|c|}{ Initial sample at first presentation } & \multicolumn{3}{|c|}{ Follow up sample after 2-7 years } \\
\hline & \multicolumn{3}{|c|}{$C D 4^{+} T$ cells } & \multicolumn{3}{|c|}{$C D 4^{+} T$ cells } \\
\hline & $>500$ & $200-500$ & $<200$ & $>500$ & $200-500$ & $<200$ \\
\hline Number of patients & 37 & 11 & 1 & 9 & 19 & 21 \\
\hline GBV-C/HGV RNA positive & 1 & 0 & $1^{\star}$ & 4 & 6 & 0 \\
\hline \multirow[t]{3}{*}{ Anti-HGV antibody positive } & 2 & 0 & 0 & 0 & 3 & 2 \\
\hline & \multicolumn{3}{|c|}{ Ratio $\mathrm{CD}^{+} /$total lymphocytes } & \multicolumn{3}{|c|}{ Ratio $\mathrm{CD}^{+} /$total lymphocytes } \\
\hline & $>0.35$ & $0.1-0.35$ & $<0.1$ & $>0.35$ & $0.1-0.35$ & $<0.1$ \\
\hline Number of patients & 11 & 37 & 1 & 2 & 27 & 20 \\
\hline GBV-C/HGV RNA positive & 0 & $2^{\star}$ & 0 & 0 & 10 & 0 \\
\hline Anti-HGV antibody positive & $1 \dagger$ & $1 \dagger$ & 0 & 0 & 3 & 2 \\
\hline
\end{tabular}

$\mathrm{CD}^{+}$denotes CD4 positive lymphocytes, expressed in absolute count $/ \mu 1$.

Ratio $\mathrm{CD} 4^{+} /$total lymphocytes denotes the ratio of absolute count of CD 4 positive cells/ $\mu 1$ and absolute count of lymphocytes/ $/ \mu 1$. ${ }^{\star}$ One patient GBV-C/HGV-RNA negative in follow up sample.

†Anti-HGV antibody negative in follow up sample.

B. In all cases haemophilia was classified as severe (serum factor VIII or IX $<1 \%$ of normal). All patients received twice to four times weekly prophylactic clotting factor substitution of 25-45 IU/kg body weight. Nineteen patients had received intravenous immunoglobulin during the follow up as part of another study. ${ }^{14}$

LABORATORY TESTS

At regular review three to six times a year, apart from a clinical and neurological examination, we analysed each patient for rises in alanine aminotransferase (ALT), aspartate aminotransferase (AST), serum bilirubin, and alkaline phosphatase; in addition, we counted $\mathrm{CD} 4^{+} \mathrm{T}$ cells and measured HIV p24 antigen concentrations.

VIROLOGICAL INVESTIGATIONS

We analysed sera for HIV (anti-HIV IgG antibody) and co-infection with HCV (anti-HCV antibody; second generation enzyme linked immunosorbent assay (ELISA)), using commercially available radioimmunoassays and enzyme immunoassays (Abbott, Wiesbaden, Germany, and Sorin, Düsseldorf, Germany, respectively); HCV RNA was determined using a reverse transcriptase polymerase chain reaction (RT-PCR) assay (HCV Amplicor kit; Roche Diagnostic Systems Inc, Branchburg New Jersey, USA).

We stored the patients' first (1987/88) and last follow up samples (1993/94 or last serum before death) at $-20^{\circ} \mathrm{C}$ and analysed them for GBV-C/HGV RNA, detected by RT-PCR with primer pairs of the helicase region of GBV-C/ $\mathrm{HGV}$, as described previously. ${ }^{6-9}$ This assay has been shown to have high specificity and sensitivity. ${ }^{15}$ We determined anti-HGV antibodies using an ELISA that detected antibodies to the HGV E2 antigen, which usually appear with loss of detectable $\mathrm{HGV}$ viraemia, indicating recovery from $\mathrm{HGV}$ infection. ${ }^{16}$

STATISTICS

Significance of differences between mean concentrations of aminotransferases and $\mathrm{CD} 4^{+}$ $T$ cell counts were compared using the MannWhitney U test. Values were expressed as mean (SD) unless otherwise stated. p Values $<0.05$ were considered significant.

\section{Results}

Four of 49 patients showed markers of previous or ongoing GBV-C/HGV infection in the first available serum sample, collected in 1987 or 1988. In two patients, GBV-C/HGV RNA could be detected; two were anti-HGV antibody positive. In one of the two patients who were GBV-C/HGV RNA positive in the initial sample, no GBV-C/HGV RNA was detected in the follow up sample, collected 4.5 years after the initial sample. This patient remained anti-HGV antibody negative in the follow up sample. Both patients who were initially anti-HGV antibody positive became antibody negative in the follow up sample after intervals of 7.6 and 7.7 years, respectively.

In the follow up samples, 15 of 49 patients had markers of GBV-C/HGV infection. Compared with the initial sample, emergence of GBV-C/HGV RNA was seen in nine patients after a median of 6 years 10 months (range, 2-7 years); five further patients became anti-HGV antibody positive. Thus, 14 patients developed markers of $\mathrm{GBV}-\mathrm{C} / \mathrm{HGV}$ infection during treatment with virus inactivated concentrates. Three of the $10 \mathrm{GBV}-\mathrm{C} / \mathrm{HGV}$ RNA positive patients and one of the five anti-HGV antibody positive patients had received intravenous immunoglobulin during the follow up as part of another study ${ }^{14}$; none of the remaining 11 patients had received any blood products except clotting factor concentrates.

Forty two of 49 patients were anti-HCV antibody positive at initial presentation. One patient was anti-HCV antibody positive, but HCV RNA negative, and one patient was HCV RNA positive, but anti-HCV antibody negative. Between first and follow up samples no evidence of new $\mathrm{HCV}$ infection was seen (positive anti-HCV antibody or HCV RNA)

All GBV-C/HGV RNA positive patients ( $n=10$ ) were co-infected with HCV and none showed a significant rise of serum ALT/AST concentration in comparison with GBV-C/ HGV RNA negative patients $(\mathrm{n}=32)$ (ALT: mean (SD), 46.2 (26.5) U/1 $v 32.9$ (23.6), respectively; AST: 23.7 (11.6) U/1 $v 26.8$ (17.5), respectively; both $\mathrm{p}>0.05)$.

During the follow up, immune function deteriorated in many patients, as reflected by 
absolute and relative $\mathrm{CD} 4^{+} \mathrm{T}$ cell counts. Table 1 shows the frequency of GBV-C/HGV RNA and antibody seropositivity in relation to $\mathrm{CD} 4^{+}$ $\mathrm{T}$ cell count. At follow up, the mean $\mathrm{CD} 4^{+} \mathrm{T}$ cell count was significantly higher in GBV-C/HGV RNA positive patients $(n=10)$ compared with GBV-C/HGV RNA negative patients $(\mathrm{n}=32)$ (mean (SD) 425.3 (175.4) v 221.9 (249.9); $\mathrm{p}<0.05)$

Fourteen patients died between 1987 and 1995, 12 of AIDS related causes. Two patients developed fulminant hepatitis. One was anti$\mathrm{HGV}$ antibody positive. GBV-C/HGV RNA could not be detected in these two patients nor in the remaining 12 patients who died.

\section{Discussion}

With a frequency of $4.1 \%$ and $20.4 \%$ in the initial and follow up samples, respectively, the prevalence of $\mathrm{GBV}-\mathrm{C} / \mathrm{HGV}$-infection was rather low in this highly virus exposed population, in which most patients were HCV RNA positive and all were HIV infected.

The most intriguing result is the high number of patients who developed markers of GBV-C/HGV infection during a period of administration of clotting factor concentrates that were considered to have undergone virus inactivation. Early dry heating methods had been used before 1987 and had been shown to reduce or remove the risk of HIV infection, but not to prevent $\mathrm{HCV}$ infection. ${ }^{17}{ }^{18}$ Despite the advent of viricidal methods such as heating to temperatures of $80^{\circ} \mathrm{C}, \mathrm{GBV}-\mathrm{C} / \mathrm{HGV} \mathrm{RNA}$ has been detected in clotting factor concentrates of several manufacturers. ${ }^{13}$ Thus, transmission of GBV-C/HGV to recipients of such concentrates may be possible, although it is unknown whether a positive RT-PCR result in these batches indicates infectiousness. De Filippi and co-workers found a low rate of viraemia in their study on GBV-C/HGV infection in adult HIV negative, multitransfused patients with haemophilia, but a high rate of anti-HGV antibody positivity, and they suggested that transmission of GBV-C/HGV (unlike HCV) does not establish long term viraemia in recipients of clotting factor concentrates. ${ }^{12}$

Two hypotheses could explain the emergence of $\mathrm{HGV}$ infection markers during the follow up of our cohort: either the patients have been infected with GBV-C/HGV by "virus inactivated" clotting factor concentrates during the follow up period or, alternatively, deterioration of immune function as a result of HIV infection has led to an increase of GBV-C/ HGV RNA concentrations above the detection limit of the assay. In the latter case, transmission of GBV-C/HGV would have taken place before switching to virus inactivated clotting factor concentrates. However, we favour the first hypothesis of GBV-C/HGV transmission by infected clotting factor concentrates during the follow up, because we did not find an obvious association between the emergence of markers of GBV-C/HGV infection and low $\mathrm{CD}^{+} \mathrm{T}$ cell counts (table 1 ). In contrast, we have found a higher proportion of $\mathrm{GBV}-\mathrm{C} /$ HGV RNA positive patients in the group with moderately decreased $\mathrm{CD}^{+} \mathrm{T}$ cell counts
(200-500/ $\mu 1)$ compared with the group with $\mathrm{CD} 4^{+} \mathrm{T}$ cell counts below $200 / \mu \mathrm{l}$. CD $4^{+} \mathrm{T}$ cell counts in $\mathrm{GBV}-\mathrm{C} / \mathrm{HGV}$ viraemic patients were significantly higher compared with GBV-C/ HGV RNA negative patients, a finding that has been reported previously in adult HIV infected patients, among whom it was suggested that GBV-C/HGV infection might be a favourable prognostic factor in HIV disease. ${ }^{19} 20$

Compared with HCV infection markers, the proportion of patients with either anti-HGV antibodies or GBV-C/HGV RNA seropositivity was lower. However, the biological importance of anti-HGV E2 antibodies as a marker of anti$\mathrm{HGV}$ seroconversion is not completely understood. It is still not known how long anti-HGV E2 antibody persists after seroconversion. Furthermore, there are no data as to whether immunocompromised patients such as ours are able to develop and maintain anti-HGV E2 seropositivity as a marker of recovery from HGV infection. In one patient in whom GBVC/HGV RNA became undetectable, no antiHGV E2 antibody response was seen. This might indicate that the real frequency of GBV$\mathrm{C} / \mathrm{HGV}$ infection may be higher than is determined using these two markers alone.

As in previous studies, no aggravation of liver disease was seen in association with the emergence of markers of GBV-C/HGV infection. Although some authors report fulminant hepatic failure in association with GBV-C/ HGV infection, ${ }^{45}$ there was no evidence of active $\mathrm{GBV}-\mathrm{C} / \mathrm{HGV}$ infection as an underlying cause in either of the two patients with fulminant hepatic failure in our series.

In conclusion, we suggest that the development of markers of GBV-C/HGV infection in our patients was the result of $\mathrm{GBV}-\mathrm{C} / \mathrm{HGV}$ infection acquired during treatment with clotting factor concentrates containing GBV-C/ $\mathrm{HGV}$, despite virus inactivation steps. However, we cannot rule out an emergence of GBV-C/HGV after earlier infection as a result of the deteriorating immune function in the course of HIV infection. As long as it remains unknown whether GBV-C/HGV RNA positivity in clotting factor concentrates represents infectiousness, further studies are necessary to ascertain whether the current inactivation methods really produce virus free preparations, even if GBV-C/HGV seems to be a virus that does little harm to the recipient.

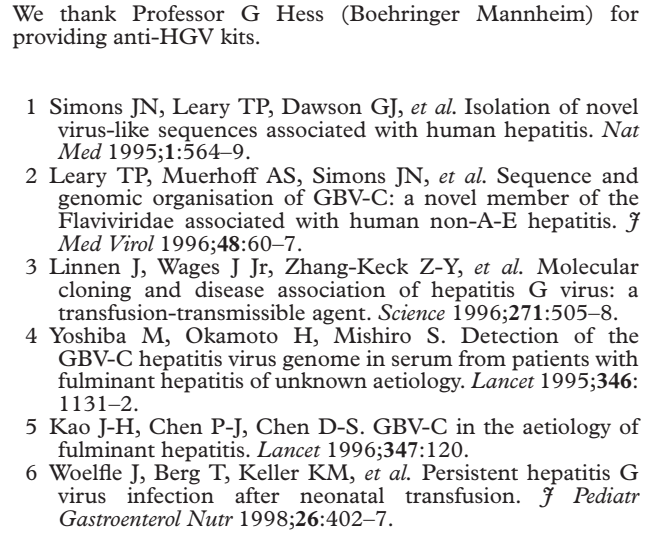

1 Simons JN, Leary TP, Dawson GJ, et al. Isolation of novel virus-like sequences associated with human hepatitis. Nat Med 1995;1:564-9.

2 Leary TP, Muerhoff AS, Simons JN, et al. Sequence and genomic organisation of GBV-C: a novel member of the Flaviviridae associated with human non-A-E hepatitis. $\mathcal{F}$ Med Virol 1996;48:60-7.

3 Linnen J, Wages J Jr, Zhang-Keck Z-Y, et al. Molecular cloning and disease association of hepatitis $G$ virus: a ransfusion-transmissible agent. Science 1996;271:505-8.

4 Yoshiba $\mathrm{M}$, Okamoto $\mathrm{H}$, Mishiro S. Detection of the GBV-C hepatitis virus genome in serum from patients with fulminant hepatitis of unknown aetiology. Lancet 1995:346: $1131-2$.

5 Kao J-H, Chen P-J, Chen D-S. GBV-C in the aetiology of fulminant hepatitis. Lancet 1996;347:120.

6 Woelfle J, Berg T, Keller KM, et al. Persistent hepatitis G virus infection after neonatal transfusion. $\mathcal{F}$ Pediatr Gastroenterol Nutr 1998;26:402-7. 
7 Schreier E, Hohne M, Kuenkel U, et al. Hepatitis GBV-C sequences in patients infected with HCV contaminated Hepatol 1996;25:385-9.

8 Berg T, Naumann U, Fukumoto T, et al. GB virus C infection in patients with chronic hepatitis $\mathrm{B}$ and $\mathrm{C}$ before and after liver transplantation. Transplantation 1996;62: $711-42$

9 Berg T, Dirla U, Naumann U, et al. Responsiveness of interferon alpha treatment in patients with chronic hepatitis $C$ coinfected with hepatitis G virus. F Hepatol 1996;25:763-8.

10 Jarvis LM, Davidson F, Hanley JP, et al. Infection with hepatitis $\mathrm{G}$ virus among recipients of plasma products. Lancet 1996;348:1352-5.

11 Tong CY, Sallam TA, Williams H, et al. Hepatitis G virus RNA and its relation to hepatitis $\mathrm{C}$ infection in adult haemophilic patients. Br f Haematol 1997;99:295-7.

12 De Filippi F, Colombo M, Rumi MG, et al. High rates of hepatitis $\mathrm{G}$ virus infection in multitransfused patients with hemophilia. Blood 1997;90:4634-7.

13 Garcia-Trevijano ER, Lopez-Alcorocho JM, Quintana M, et al. HGV in coagulation-factor concentrates. Lancet 1996; 348:1032.
14 Wagner, N, Bialek R, Radinger $\mathrm{H}$, et al. Intravenous immunoglobulin in HIV-1 infected haemophilic patients. Arch Dis Child 1992;67:1267-71.

15 Künkel U, Höhne M, Berg T, et al. Quality control study on the performance of $\mathrm{GB}$ virus $\mathrm{C} /$ hepatitis $\mathrm{G}$ virus PCR. $\mathcal{F}$ Hepatol 1998;28:978-84

16 Tacke M, Kiyosawa K, Stark K, et al. Detection of antibodies to a putative hepatitis $\mathrm{G}$ virus envelope protein. Lancet 1997;349:318-20.

17 Mannucci PM. The choice of plasma-derived clotting factor concentrates. Ballieres Clin Haematol 1996;9:273.

18 Allain JP, Dailey SH, Laurian Y, et al. Evidence for persistent hepatitis C virus (HCV) infection in hemophiliacs. $\mathcal{F}$ Clin Invest 1991;88:1672-9.

19 Heringlake S, Ockenga J, Tillmann HL, et al. GB virus $\mathrm{C} /$ hepatitis $\mathrm{G}$ virus infection: a favorable prognostic factor in human immunodeficiency virus-infected patients? $\mathcal{F}$ Infect Dis 1998;177:1723-6.

20 Bonacini M, Qian D, Govindarajan S, et al. Prevalence of hepatitis G virus RNA in the sera of patients with HIV infection. I Acquir Immune Defic Syndr Hum Retrovirol 